\title{
THE PROBLEM OF ABANDONED PROPERTY AFTER THE ENTRY INTO FORCE OF THE DECREE ON OWNERSHIP AND USE OF LANDS IN THE CAPITAL CITY OF WARSAW
}

\author{
PROBLEMATYKA MIENIA OPUSZCZONEGO PO WEJŚCIU W ŻYCIE DEKRETU \\ O WŁASNOŚCI I UŻYTKOWANIU GRUNTÓW NA TERENIE M. ST. WARSZAWY
}

https://doi.org/10.34739/zn.2021.56.06

Monika Abramowska

Poland, University SWPS of Humanities and Social Sciences in Warsaw m.abramowska@hotmail.com, ORCID: 0000-0001-6996-6717

\begin{abstract}
This article attempts to answer the question of whether abandoned property existed in Warsaw after the entry into force of the Decree on Warsaw Lands. Contemporary case law is consistent in the position that within the territory of the capital of Poland, after the entry into force of the Decree on Warsaw Lands, there was no abandoned property given the categorical wording of Article 1 of the Decree that on the date of entry into force, all Warsaw lands are transferred to the municipality of the Capital City of Warsaw. However, post-war doctrine is of the opinion that for the transfer of ownership it was necessary to enter the new owner in the land and mortgage register.
\end{abstract}

Keywords: abandoned estates, abandoned property, Decree on Warsaw Lands, ownership

\begin{abstract}
Streszczenie: W artykule podjęto próbę odpowiedzi na pytanie, czy na obszarze Warszawy, po wejściu w życie dekretu o gruntach warszawskich, istniało mienie opuszczone. Współczesne orzecznictwo konsekwentnie stoi na stanowisku, iż na terenie stolicy Polski po wejściu w życie dekretu o gruntach warszawskich nie istniały majątki opuszczone. Z uwagi na fakt kategorycznego brzmienia art. 1 dekretu, iż z dniem jego wejścia w życie przechodzą na własność gm. m. st. Warszawy wszelkie grunty. Jednakże powojenna doktryna jest zdania, iż do przejścia własności konieczne było uwidocznienie nowego właściciela w księdze wieczystej.

Słowa kluczowe: majątki opuszczone, mienie opuszczone, dekret o gruntach warszawskich, własność
\end{abstract}

\section{Introduction}

Although over 70 years have passed since the entry into force of provisions on abandoned and derelict property, there remains a current answer to the question of whether there could have been abandoned property in Warsaw after the Second World War. This issue is of particular importance for people who still have unapproved decreerelated applications lodged pursuant to Article 7(1) of the Decree of 26 October 1945 on Ownership and Use of Lands in the Capital City of Warsaw (Journal of Laws of 1945, No. 50, item 279, as amended [Dz.U. z 1945 r., Nr 50 poz. 279 z późn. $\mathrm{zm}$.]) ("Decree on Warsaw Lands"), despite the fact that they were submitted by the legally required deadline.
It must be noted that the first legal act regulating the matter of abandoned property was the Decree of 2 March 1945 on Abandoned and Derelict Property (Journal of Laws of 1945, No. 9, item 45 [Dz.U. z 1945 r., Nr 9 poz. 45 z późn. zm.]). It lost legal force due to the fact that it was not presented by the Presidium of the State National Council [Prezydium Krajowej Rady Narodowej] for approval by the State National Council [Krajowa Rada Narodowa]. Therefore, it was replaced by the Act of 6 May 1945 on Abandoned and Derelict Properties (Journal of Laws of 1945, No. 17, item 97, as amended [Dz.U. z 1945 r., Nr 17 poz. 97 z późn. zm.]), which was repealed on 19 April 1946 by way of Article 41 of the Decree of 8 March 1946 on Abandoned and Post-German Property (Journal of Laws of 1946, No. 13, item 87, as 
amended [Dz.U. z 1946 r., Nr 13 poz. 87 z późn. $z m]$.$) .$

The common legislative motive of the abovementioned legal acts was to put the problems of abandoned and post-German property in order. The Act of 6 May 1945 on Abandoned and Derelict Property states that "Any personal or real property that in connection with the war that began on 1 September 1939 is not in the possession of the owner, or their legal successors or legal representatives is abandoned property". Within the meaning of the provisions on 1946 (Journal of Laws of 1946, No. 13, item 87, as amended [Dz.U. z 1946 r., Nr 13 poz. 87 z późn. zm.]), abandoned property in accordance with Article 1(1) was "any property (personal or real) of persons who in connection with the war that began on 1 September 1939 lost possession of it and then did not regain it." Both acts additionally state that abandoned property is considered also to be property (personal or real) that is in the possession of third parties pursuant to an agreement concluded with the owner, or their legal successors or legal representatives acting in the interests of these persons, if this agreement was aimed at protecting this property against loss in connection with the war or occupation.

At the time of entry into force of the Decree on Warsaw Lands, regulations on abandoned property had been applied throughout Poland for a long time, including in the capital, mainly in order to put in order the ownership status of real estate in connection with cases where it is impossible to determine the fate of the existing rightholders and to protect their interests. Given the above, there should be no doubt that abandoned property existed in the capital of Poland.

It should be highlighted that the Decree on Warsaw Lands was one of the main legal acts under the package of normative regulations regarding rebuilding the country after World War II. However, without taking into account and analysing some accompanying legal acts, one cannot understand it properly and be able to apply the mechanisms adopted by the legislator at the time. Therefore, an interpretation of the Decree on Warsaw Lands must systemically include the content of other legal acts, with particular emphasis on:

a) the Decree of 8 March 1946 on Abandoned and Post-German Property, formerly the Decree of 2 March 1945 on Abandoned and Derelict Property, and the Act of 6 May 1945 on Abandoned and Derelict Property.

b) the Decree of 26 October 1945 on the Demolition and Repair of Buildings Destroyed and Damaged as a result of the War (Journal of
Laws of 1945 , No. 50 , item 281 , as amended [Dz.U. z 1945 r., Nr 50, poz. 281 z późn. zm.]), c) the Act of 3 July 1947 on Supporting the Construction Industry (Journal of Laws of 1947, No. 52, item 270 as amended [Dz.U. z 1947 r., Nr 52, poz. 270 z późn. Zm.]).

\section{Literature}

The scope of the available literature is satisfactory; however, most publications concern a broader subject, namely, ownership rights, property management, expropriation and compensation. In recent years, there have also been many pieces about the Decree on Warsaw Lands, including in the area of reprivatisation.

Unfortunately, the area of abandoned property in Warsaw does not get as much attention. To date, there has been no comprehensive report on this issue. Limited materials come from the post-war years.

\section{Research methodology}

A formal and dogmatic method was used in the research to interpret the relevant provisions about abandoned property. To this end, reference was made to the case law of common courts, administrative courts and the Constitutional Tribunal [Trybunał Konstytucyjny]. There is also a review of the literature on the said issues.

\section{Results and discussion}

It should be noted that the regulations of 1945 (Journal of Laws of 1945, No. 17, item 97, as amended [Dz.U. z 1945 r., Nr 17 poz. 97 z późn. $\mathrm{zm}$.]), were derived from the so-called ownership approach. On the other hand, the legislator, in the decree of 1946 (Journal of Laws of 1946, No. 13, item 87, as amended [Dz.U. z 1946 r., Nr 13 poz. $87 \mathrm{z}$ późn. zm.]) did not adopt the right of ownership as the decisive criterion for assessing the nature of property, but the fact of having been in possession of the property at the time of its loss. This change should be viewed positively, because if the original version of the definition of abandoned property were to be kept, any ownership changes that would have taken place during World War II (even during World War II, purchase and sale transactions were concluded) and after it would make it impossible for the new buyer to recover the lost property based on the Decree of 8 March 1946 on Abandoned and Post-German Property.

An interpretation of the definition of abandoned property can also be found in post-war case law, as the Supreme Court [Sąd Najwyższy] in the 
judgement of 10 November 1948, case reference number C 730/48, OSNC 1949, Nos. 2-3, item 49 indicated that:

\begin{abstract}
"(...) the term "in connection with the war that began on 1 September 1939" from Article 1 of the decree cannot be explained narrowly. This relationship may be both direct and indirect, and will occur, in particular, in any event in which, depending on the circumstances, it will be justified to infer that the loss of ownership occurred in some causal link with the ongoing war, or if one would like to express the same in a negative way, that such a loss of property would have occurred if the war had not started at all. The deprivation of all people of Jewish nationality in the territory of Poland of possessing their property as a result of the confiscation of these properties, transporting these people to camps and murdering the owners of the properties by the German authorities is one of the most mass-scale and typical phenomena of the loss of property in connection with the war, and thus the reason for the creation of abandoned property within the meaning of Article 1 of the decree. Without the war, such a loss would not have occurred."
\end{abstract}

It is worth adding that pursuant to the provisions of the Decree of 8 March 1946 on Abandoned and Post-German Property, the acquisition of ownership of post-German property by the State Treasury [Skarb Państwa] occurred ex lege (Article 2), while the acquisition of post-German property abandoned with the expiry of the time limits provided for by the Decree due to the longterm inactivity of the owner (Article 34(1)(a) or (3)) occurred due to limitation ("prescription"): for real property after ten years, and for personal property after five years from the end of the calendar year in which the war ended. In the light of the above, Article 34 of the Decree of 1946 (Journal of Laws of 1946, No. 13, item 87 as amended [Dz.U. z 1946 r., $\mathrm{Nr} 13$ poz. 87 z późn. zm.]) should not be included in the nationalisation acts, as it was only intended to protect the property of the former owners against destruction (Ziętek, 2010).

Post-war case law also features a similar view - that the main goal of the Decree of 8 March 1946 on Abandoned and Post-German Property was to protect the property of citizens who in connection with the war lost possession of it against devastation and theft. The nationalisation of property on this basis was a last resort that prevented the economically harmful state of temporariness, which obviously could not last indefinitely (see the resolution the Supreme Court in full composition of its Civil Chamber of 24 May 1956 with an addendum of 26 October 1956, file reference number 1 CO 9/56, OSN 1957, No. 1 [uchwała Pełnego Składu Izby Cywilnej Sądu
Najwyższego $z$ dnia 24 maja $1956 \quad r$. z uzupełnieniem z dnia 26 października 1956 r., sygn. akt 1 CO 9/56, OSN 1957, nr 1]).

It is also worth citing the position of the Constitutional Tribunal [Trybunału Konstytucyjnego], which in its decision of 24 October 2000, file reference number SK 31/99, OTK 2000 No. 7 , item 262 [postanowienie $z$ dnia 24 października 2000 r., sygn. akt SK 31/99, OTK 2000 nr 7, poz. 262], found that:

\begin{abstract}
"Pursuant to the legal definition in Article 1(1) of the Decree, "abandoned property is any property (personal or real) of persons who in connection with the war that began on 1 September 1939 lost possession of it and then did not regain it." This definition, apart from the criteria of nationality and citizenship of the owners, from the date of and reasons for the loss of possession covered all properties whose owners lost their actual control over them due to the war. As the Supreme Court explained in the resolution of 26 October 1956, the main goal of the provisions on abandoned property was to protect the property of citizens who in connection with the war lost possession of it (OSN 1957, item 1). The fate of the abandoned property depended on the attitude of the owner. The Decree of 8 March 1946 in Article 15 provided for the return of ownership at the request of the interested party submitted by 31 December 1948".
\end{abstract}

The main difference between the individual acts on abandoned property was that the Decree of 8 March 1946 on Abandoned and Post-German Property established, in place of the Main Office of the Temporary State Board [Główny Urząd Tymczasowego Zarządu Państwowego] consisting of the Main Board [Zarząd Główny] and voivodship boards [zarządów wojewódzkich], District Liquidation Offices [Rejonowe Urzędy Likwidacyjne] as first instance institutions and Regional Liquidation Offices [Okręgowe Urzędy Likwidacyjne] as second instance bodies. Their jurisdiction included securing property until it was taken over by the competent authorities. These bodies could rent or lease the abandoned properties and perform other activities specified in the provisions. The liquidation offices were eliminated pursuant to Article 36(1) of the Act of 20 March 1950 on Local Bodies and Uniform State Authority (Journal of Laws of 1950, No. 14, item 130, as amended), and their rights and obligations were taken over by the Poviat and Voivodship Financial Departments [Powiatowe i Wojewódzkie Wydziały Finansowe] (Sztyk, 2004).

It should be added that there were great difficulties in the implementations of the provisions of these legal acts, in particular due to the general and imprecise provisions, and often also due to the 
absence of arrangements for specific scopes, at least in the form of regulations. This contributed significantly to the issuance of further acts that were meant to facilitate dealing with matters related to abandoned property. It should be noted that in the post-war years, specific decisions were often made and attempts to pass legal acts to sanction these decisions were made later.

The technical issues related to abandoned property have been explained by the Supreme Court [Sąd Najwyższy] in the Resolution of the Panel of Seven Judges of 7 February 1959 (Resolution of the Panel of Seven Judges of the Supreme Court of 7 February 1959, I CO 32/58, OSNCK 1960, No. 3, item 61 [uchwała Składu Siedmiu Sędziów z dnia 7 lutego 1959 r., sygn. akt I CO 32/58, OSNCK 1960, nr 3, poz. 61]), in which it specified that in order to find that a property was taken over based on the decree [on abandoned and post-German property] (Journal of Laws of 1946, No. 13, item 87 as amended [Dz.U. z 1946 r., Nr 13 poz. 87 z późn. zm.]), it is not enough for it to have been actually taken over by liquidation bodies. In addition to this, these bodies must have also taken actions to indicate that they took over the property in order to exercise the rights and obligations vested in the liquidation offices by law. Such actions included, for example, the preparation of a property takeover report, entering the property in the Register of Abandoned and Post-German Property, the transfer of the property by the liquidation body to the management of another unit, as well as any letters showing that the property was treated as an abandoned property (Ziętek, 2010).

Given the above, there should be no doubt that abandoned property existed in the capital of Poland. Originally, this was both developed and undeveloped real property, as well as personal property, because all property of persons who in connection with the war that began on 1 September 1939 lost possession of it and then did not regain it became abandoned property. After the entry into force of the Decree on Warsaw Lands and after the municipality took material possession of land, first and foremost, movables and buildings that were the subject of separate ownership, and that pursuant to Article 5 of the Decree (Journal of Laws of 1945 , No. 50, item 279, as amended [Dz.U. z 1945 r., Nr 50 poz. 279 z późn. zm.]) were owned by the current owners became abandoned property. Due to earlier warfare and other repressions, not all residents of the capital returned to their homes immediately after the war ended, and thus, could quickly regain possession of them on the basis of an appropriate administrative or court procedure.
It must be added that $E$. Łętowska in her memo from 2 August 2017 published at https://konstytucyjny.pl entitled: "Mechanizm dekretu Bieruta. Dlaczego potrzebna była przesłanka posiadania?" ("The Mechanism of the Bierut Decree. Why was the possession requirement needed?") highlighted that: "analysing the problem of the Bierut Decree, it must be remembered that:

a) abandoned property existed after the war (subject to a different governing law)".

However, contemporary case law assumes that there was no abandoned property in Warsaw. This is confirmed by the view of the Supreme Administrative Court [Naczelny Sąd Administracyjny] contained in the judgement of 11 March 2016 (decision of SAC of 11 March 2016, I OSK 1306/14 [wyrok NSA z dnia 11 marca 2016 r., sygn. akt I OSK 1306/14]), that:

"(...) the decree about ownership and use of lands in the Capital City of Warsaw stated in Article 1 that all lands in the Capital City of Warsaw on the day of its entry into force are transferred to the ownership of the municipality of the Capital City of Warsaw. Already from the wording of this provision it is clear that all lands located in the Capital City of Warsaw on the day the decree entered into force became the property of the municipality of the Capital City of Warsaw. The legislator did not introduce any distinction between the nature of the lands, or exclude a specific category of lands, and so, did not exclude lands that met the conditions of an abandoned property within the meaning of the decree on abandoned and post-German property, and earlier the decree on abandoned and derelict property".

The above position is embedded in the case law of administrative courts, and so it is worth citing the justification of the judgement of the Supreme Administrative Court [Naczelny Sąd Administracyjny] of 15 March 2005 (decision of SAC of 11 March 2005, OSK 8/04 [wyrok NSA z dnia 11 marca 2005 r., sygn. akt I OSK 8/04]), which indicated that:

\footnotetext{
"Regional liquidation bodies have been created pursuant to the provisions of the decree of 8 March 1946 on abandoned and post-German property (Journal of Laws 1946, No. 13, item 87) regulating matters related to the property of persons who in connection with the war that began on 1 September 1939 lost possession of it and then did not regain it. Provisions about abandoned (derelict) property specified the scope of tasks of liquidation bodies related to the need to secure these properties. In addition to the above-mentioned regulation, there is also the regulation of the ownership and use of land in the Capital City of Warsaw in the decree of
} 
26 October 1945 (Journal of Laws 1945 No. 50, item 279). Article 1 of this Decree provides for the transfer on the day of its entry into force of all lands in the Capital City of Warsaw to the municipality of the Capital City of Warsaw. However, pursuant to Article 7(1) of the Decree, the current owners of the land or the legal successors of the owners who possess the land or the persons representing their rights could, within six months from the day the municipality took possession of the land, submit an application for a perpetual lease of this land. Such a regulation meant that land in Warsaw could not be treated as abandoned (derelict) property, and thus the provisions governing the functioning of liquidation offices did not apply to this land".

Given the above, the position of I. Chabielski (Chabielski, 1946, 74) in June 1947 must be highlighted: "The act on ownership and use of land in the Capital City of Warsaw does not automatically transfer the ownership of the land to the municipality on the day the decree is announced, i.e. on 21 November 1945. However, the takeover of the ownership right has its own sanctioned forms (Article 2). This moment will be the transfer of the titles to the municipality."

In addition, I. Chabielski added thatthe Abandoned Property Board[see: the Department of the Abandoned Property Board (Referat Zarządu Mienia Opuszczonego) is a unit of the Board of Independent Cities (Zarząd Miast Wydzielonych) appointed to administer the property after occupation by Germany and its allies, after the citizens of the German state (Reichsdeutsche), persons of German nationality (Volksliste I and II), so-called "Volksdeutsche" from the former General Government (Generalna Gubernia), citizens of allied countries and property abandoned or not yet taken over by the legal owners on the basis of the Order of the Silesian Voivode (Zarzadzenie Wojewody Śląskiego) of 22 February 1945 on the establishment of a Special Liquidation and Control Commission at the Silesian Voivodship Office (Specjalna Komisja Likwidacyjno-Kontrolna przy Urzędzie Województwa Śląskiego) for the liquidation and control of post-German and abandoned property - published in the official Gazette of the Silesian Voivodship (Gazeta Urzędowa Województwa Śląskiego) on 7 March 1945, No. 2, item 24]"followed the same path, drawing up a formal agreement for the operation of stores, of course as a quasi negotiorum gestor of the owner. That is why given such numerous applications submitted to Municipal Court for the return of possession, it is realistic and right to reserve the rights of the municipality as regards the land itself, and it is not right to leave requests for the use of the land limited only to the use of buildings unconsidered" (Chabielski, 1946, 74).

The above fragment shows that during the introduction of the provisions of the Decree on Warsaw Lands, a lot of attention was paid to the formal transfer of the right of ownership to the municipality of the Capital City of Warsaw in the form of entering the new owner in the land and mortgage registers. Equally important was the moment of actual possession of the said land by the municipality of the Capital City of Warsaw. It should be added that it is not about the taking over on the day of the issue of the edition of the Official Journal of the National Council and the City Council of the Capital City of Warsaw [Dziennik Urzędowy Rady Narodowej i Zarząd Miejski m. st. Warszawy], considered to be so-called normative possession independent of the actual control over the object (corpus) (Zaradkiewicz, 1/19 June). Therefore, it should be noted that for the transfer of ownership of Warsaw land to the municipality of the Capital City of Warsaw, the date of entry into force of the provisions of the Decree on Warsaw Land had no bearing.

Finally, it is worth stating that applications for the return of ownership submitted by owners of Warsaw lands to Municipal Courts in Warsaw [Sądy Grodzkie w Warszawie] were not rare. Often, decree files have the originals of these enforcement orders together with documents from the judicial officers who oversaw the rightful owner of a property in Warsaw returning to the possession of the abandoned property.

\section{Conclusions}

With our final deliberations, it is worth determining the date of the transfer of the ownership of the Warsaw land to the municipality of the Capital City of Warsaw. However, it should be noted that, as the Voivodship Administrative Court in Warsaw [Wojewódzki Sąd Administracyjny w Warszawie] highlighted in the judgement of 19 February 2020 (decision of VAC in Warsaw of 19 February 2020, I SA/Wa 2033/19) [wyrok WSA w Warszawie z dnia 19 lutego 2020 r., sygn. akt I SA/Wa 2033/19]:

\footnotetext{
"As at the date of entry into force of the Warsaw Decree, in the territory of the Capital City of Warsaw as regards legal and material relations, the provisions contained in the Napoleonic Code and the law on establishing the ownership of immovable goods, on privileges and mortgages of 26 April 1818 were in force in the wording given by the ordinance of the General Commissioner for the Eastern Territories of 3 August 1919 (Journal of Laws of 1928, No. 53, item 510)".
} 
On the other hand, R. Strzelczyk (Strzelczyk, $2011,12)$ rightly added that:

\begin{abstract}
"According to Article 5 of the mortgage law of 1818 , the entry of the ownership of the real estate was of a law-making nature. This provision provided that the right to control the real estate was acquired by entering the purchase title into the mortgage registers. The doctrine and case law of that time consistently showed that since real estate can only be controlled by the owner, and the right to dispose is acquired at the time the entry is made, which means that ownership of the real estate is also acquired at the time the entry is made".
\end{abstract}

On the date of entry into force of the Decree on Warsaw Lands, in order to acquire the ownership right to Warsaw land, the new owner had to be entered in the land and mortgage register - in this case, it was the municipality of the Capital City of Warsaw. The date of the change was the date on which the ownership right was acquired. Given the above, it should be found that after the entry into force of the Decree on Warsaw Lands, abandoned property existed in the capital of Poland, and this was both developed and undeveloped real property, as well as personal property, because all property of persons who in connection with the war that began on 1 September 1939 lost possession of it and then did not regain it became abandoned property. It must be added that often, due to warfare, Warsaw's citizens left their homes and because of the extent of the damage did not return to them immediately after World War II ended.

\section{Bibliography}

\section{References:}

Bernatowicz, Ł. (2015). Reprywatyzacja na przykładzie gruntów warszawskich [Reprivatization on the example of Warsaw land]. Warszawa: Wolters Kluwer.

Chabielski, I. (1946). Odbudowa stolicy w świetle nowych dekretów [Reconstruction of the capital in the light of new decrees]. Państwo i Prawo 4, 68-76.

Ciepła, H., Sarbiński R.M., Sobczyk-Sarbińska, K. (2013). Roszczenia przysługujące byłym właścicielom tzw. gruntów warszawskich. Sposób ich dochodzenia w postępowaniu administracyjnym i sadowym [Claims due to former owners of the so-called Warsaw land. The manner of their investigation on administrative and court proceedings]. Warszawa: Wolters Kluwer.

Hoc, S. (2009). Prawo administracyjne gospodarcze: Wybrane zagadnienia [Economic administrative law: selected issues]. Warszawa: Uczelnia Łazarski.
Hetko, A. (2008). Dekret Warszawski - postępujące wywłaszczenie nieruchomości [Warsaw Decree - progressive expropriation of real estate]. Warszawa: C.H. Beck.

Hetko, A. (2012). Dekret warszawski. Wybrane aspekty systemowe [Warsaw Decree. Selected system aspects]. Warszawa: C.H. Beck.

Łętowska, E. (2017). Mechanizm dekretu Bieruta. Dlaczego potrzebna była przesłanka posiadania? Retrieved from: https://konstytucyjny.pl/.

Potasznik, W. (2005). Utracone majątki. Zwrot i odszkodowania. [Lost assets. Refund and compensation]. Warszawa: Potasznik.

Siciński, P. (2002). Ujawnianie w księgach wieczystych praw i roszczeń dotyczących gruntów na obszarze m.st. Warszawy, opartych na przepisach dekretu z dnia 26 października 1946 r. [Disclosure in land and mortgage registers of rights and claims regarding land in the area of the capital city of Warsaw, based on the provisions of the decree of October 26, 1946]. Rejent 10, 116-128.

Strus, Z. (2007). Grunty warszawskie [Warsaw lands]. Przegląd Sądowy 10, 28-34.

Strzelczyk, R. (2016). Prawo obrotu nieruchomościami [Real estate law]. Warszawa: C.H. Beck.

Strzelczyk, R. (2011). Prawo nieruchomości [Real estate law]. Warszawa: C.H. Beck.

Sztyk, R. (2004). Nieruchomości opuszczone i poniemieckie w praktyce notarialnej [Abandoned and post-German properties in notary practice]. Rejent 7, 176-196.

Zaradkiewicz, K. (2019). Posiadanie jako przesłanka nabycia roszczeń $z$ dekretu warszawskiego [Possession as a premise for the acquisition of claims under the Warsaw Decree]. Nieruchomości. Wykładania i stosowanie prawa 1/19 13-44.

Ziętek, W. (2010). Nabycie prawa własności nieruchomości przez Skarb Państwa w trybie przemilczenia - uwagi na tle projektu ustawy o świadczeniach pieniężnych przyznawanych niektórym osobom, których dotyczyły procesy nacjonalizacji [Acquisition of the ownership right to real estate by the State Treasury under the silence procedure - comments in the context of the draft act on monetary benefits granted to certain persons affected by nationalization processes]. Palestra 5-6, 55-62.

\section{Legal acts:}

Dekret z dnia 2 marca 1945 r. o majątkach opuszczonych i porzuconych. Dz.U. z 1945 r., nr 9, poz. 45. [the Decree of 2 March 1945 on Abandoned and Derelict Property. Journal of Laws of 1945, No. 9, item 45].

Dekret z dnia 26 października 1945 r. o własności i użytkowaniu gruntów na obszarze m.st. Warszawy. Dz.U. z 1945 r., nr 50, poz. 279 z późn. zm. [the Decree of 26 October 1945 on 
Ownership and Use of Lands in the Capital City of Warsaw. Journal of Laws of 1945, No. 50, item 279, as amended].

Dekret z dnia 26 października 1945 r. o rozbiórce i naprawie budynków zniszczonych i uszkodzonych wskutek wojny. Dz.U. z 1945 r., nr 50, poz. 281 z późń. zm. [the Decree of 26 October 1945 on the Demolition and Repair of Buildings Destroyed and Damaged as a result of the War. Journal of Laws of 1945, No. 50, item 281, as amended].

Dekret z 8 marca 1946 r. o majątkach opuszczonych i poniemieckich. Dz.U. z 1946 r., nr 13, poz. $87 \mathrm{z}$ późn. zm. [the Decree of 8 March 1946 on Abandoned and Post-German Property. Journal of Laws of 1946, No. 13, item 87 , as amended].

Ustawa z dnia 6 maja 1945 r. o majątkach opuszczonych i porzuconych. Dz.U. z 1945 r., $\mathrm{nr} 17$, poz. 97 z późn. zm. [the Act of 6 May 1945 on Abandoned and Derelict Properties. Journal of Laws of 1945, No. 17, item 97, as amended].

Ustawa z dnia 3 lipca 1947 r. o popieraniu budownictwa. Dz.U. z 1947 r., nr 52, poz. 270 z późn. zm. [the Act of 3 July 1947 on Supporting the Construction Industry (Journal of Laws of 1947, No. 52, item 270, as amended].

Ustawa z dnia 20 marca 1950 r. o terenowych organach i jednolitej władzy państwowej. Dz.U. z 1950 r., nr 14, poz. 130 z późn. zm. [the Act of 20 March 1950 on Local Bodies and Uniform State Authority. Journal of Laws of 1950, No. 14, item 130, as amended].

Rozporządzenie Komisarza Generalnego Ziem
Wschodnich z dnia 3 sierpnia 1919 r. Dz.U. 1928 r. Nr 53, poz. 510. [Order of the General Commissioner of the Eastern Territories of 3 August 1919. Journal of Laws of 1928, No. 53, item 510].

\section{Jurisdiction:}

Wyrok Wojewódzkiego Sądu Administracyjnego w Warszawie z dnia 19 lutego 2020 r., sygn. akt I SA/Wa 2033/19, niepubl.

Wyrok Naczelnego Sądu Administracyjnego z dnia 11 marca 2016 r., sygn. akt I OSK 1306/14, niepubl.

Wyrok Naczelnego Sądu Administracyjnego z dnia 15 marca 2005 r., sygn. akt OSK 8/04, niepubl.

Uchwała Składu Siedmiu Sędziów Sądu Najwyższego z dnia 7 lutego 1959 r., sygn. akt I CO 32/58, OSNCK 1960, nr 3, poz. 61.

Postanowienie Trybunału Konstytucyjnego $z$ dnia 24 października 2000 r., sygn. akt SK 31/99, OTK 2000, nr 7, poz. 262.

Uchwała Pełnego Składu Izby Cywilnej Sądu Najwyższego z dnia 24 maja 1956 r., sygn. akt 1 CO 9/56, OSN 1957, nr 1.

Wyrok Sądu Najwyższego z dnia 10 listopada 1948 r., sygn. akt C 730/48, OSNC 1949, nr 2-3, poz. 49. 